\title{
Who Made the Yardstick? An Oppressed Critique of the Comparative and the International
}

\author{
Minoli Wijetunga \\ University of Oxford, United Kingdom \\ University of Colombo, Sri Lanka
}

...the field of 'post-colonial' discourse has been defined in ways which can still leave out indigenous peoples, our ways of knowing and our current concerns.

(Smith, 2012)

There are two main ways in which comparative research is done: the yardstick comparison and the Venn comparison (Sobe, 2018). Attempting comparative research with a yardstick in hand raises the problem of who created the yardstick; answer being America or a select European country, by the virtue of resource distribution. With Venn comparison, the researcher is often located outside the circles, thus holding a position of power. Comparative learning, of course, is essential. However, in the methodological approach that is commonly seen in the field, "apples and oranges can be easily compared provided that we see them both as 'fruit.'" (Sobe, 2018, p. 333); yet, what about the tomatoes?

In the Pedagogy of the Oppressed, Freire (1972, p. 10) identifies two distinct stages of the humanist and libertarian pedagogy: one, where the oppressed "unveil the world of oppression" to commit themselves to its transformation; and the second, where the pedagogy of the oppressed "becomes a pedagogy of all people." This essay is an attempt at the first stage, to unveil an aspect of the world of oppression that exists in comparative and international education (CIE). It does so through two parallel arguments: one, through the exploration of definitions of CIE, and two, through analyzing the speeches of two CIE Society presidents delivered over a decade apart.

The surest way of critiquing a field is to compare its definition with its use; yet, with CIE the one thing comparativists agree upon is that there is no singular definition. If language defines thought (Wittgenstein, 1992), and definitions give shape to concepts, the lack of a singular definition leads one to assume that each practitioner would understand, and therefore, conceptualize comparative and international in education differently. Thus, the only way for an outsider to understand what is meant by comparative and international in education is to look at the field in practice. However, when the field is an uneven playing field, and "the clamor" is "for the immediate comprehensibility by the ideological average" and "not for clarity" (Spivak, 2003), the practice becomes one that gives voice to the hegemony and pretends to give voice to the subaltern that cannot speak.

Hegemonic, in the course of this paper, assumes a wider definition. While imperialism is one form of hegemonic exercise, the term also encompasses other forms of power 
imbalances including economic expansion, the subjugation of the 'other', and as a discursive field of knowledge. It follows the definitions put forth by Smith (2012) in "Decolonizing methodologies". Thus, this essay oscillates between colonial power as well as modes of neocolonialism. It approaches the world as one that is entrenched in an imbalance of power to argue that the current practices of CIE aid in the perpetuation of this imbalance using Ross (2002), and Sobe (2018).

The idea that CIE is hegemonic, that it perpetuates power imbalances - be it imperialism, gender inequality or racial discrimination - is not a new idea. Ross (2002) notes the need to "conceptualize the ways lives mesh, transmitting direction and power" while Sobe (2018) stresses that "our comparativist present is also contoured and shadowed by spectres of past[...] all of which arguably continues in full force today". Ross' (2002) presidential address is colored by the tragic events of $9 / 11$, thus calling more loudly than ever to evoke an ethics of care in the research to create a level playing field. Over a decade later, Sobe finds the field's work equally disturbing; these disturbances are furthered by the emergence of Big Data - yet another tool that can easily be co-opted to further silence the subaltern. For, Sobe (2018) writes, "comparison is not just an academic technique, but a style of thought and action located in particular time-spaces" (p. 334). Therefore, from Explorative age to the Post-Explorative (Sobe, 2018) these issues have remained.

As Sadler's famous quotes says, CIE approached the world as a garden of education systems, home-grown and cautioning against ad-hoc borrowing (cited in Bereday, 1964). However, this also posited that comparative education fundamentally was about countries, systems, and comparing them (Klerides, 2015). Practitioners approaching education shaped by the words of Sadler and the garden lend a hand in defining the term CIE. Unaware of the ways in which greenhouses have been created just to grow certain plants; willfully oblivious to the ways in which exotic imports and financially sound exports work in a globalized world, they operate within this narrow definition of CIE, thus contributing to the hegemonic nature of its conceptualization.

Takayama et al. (2017) identified four major textbooks in the field: Comparative Education: The Dialectic of the Global and the Local (Arnove et al., 2013); Comparative Education: Exploring Issues in International Context (Kubow \& Fossum, 2007); CIE: Issues for Teachers (Bickmore et al., 2017); and CIE: An Introduction to Theory, Method and Practice (Phillips \& Schweisfurth, 2014). This is the introduction a novice to the field has, the overview they receive. These textbooks speak of a history that starts with travellers' tales through to quantitative research. A common feature they all share, though, is the nature of the history: it is Anglo-European, relegating the other parts of the world to either the subject of benevolent bestowing of knowledge or completely invisible. Although Bickmore et al. (2017) note the existence of Chinese scholarship, it is not in the same vein as the other; on the other hand, with China being an emerging (or emergent, as some may argue) global superpower, it is evident of the expansion of the hegemony than the presence of the subaltern. Phillips and Schweisfurth (2014) note that in common usage comparative studies are "associated with the western industrialized world", and international education "implies the study of education in all its forms in the developing world", thus creating a binary. While they are firm in distancing themselves from these definitions by calling them "absurd" and "wrong", an alternative definition has not been forthcoming. Instead, these textbooks focus on the practice, the subject, and the methodology which are problematic in their own way.

This is not to say that the founders of CIE have been focused on the ideology of this independent system. Kandel, for example, stresses the importance of context, advocating 
for an inclusive approach. This is a view furthered by later scholars in the field like Bray and Epstein (Takayama et al., 2017). The field, indeed, attempts to be inclusive. The World Council of Comparative Education Societies (WCCES), for example, has 41 comparative education societies registered on their website covering considerable global geography from India to Kazakhstan to Haiti to Israel. Yet, which societies are the most funded, the most celebrated, and more importantly, which societies are spoken of the most with scholars entering the field of CIE? Reflecting on her term with the WCCES, HicklingHudson (2007) notes the lack of Asian and African representation in the international fora. Yet, the best-known comparative education society would be CIES, its work, conferences, and members being prominent scholars in the field. If the disinterest noted by HicklingHudson (2007) is to be taken as an indication of their disengagement with an introspective attempt to be inclusive, it can be concluded that there is a clear imperial power in knowledge production of CIE. Therein lies the discrepancy, which supports the notion that CIE as a field is hegemonic.

The world is now approaching, or arguably in the middle of, what Sobe (2018) calls the Post-Exploratory era, defined by Big Data. As a science, Big Data has not penetrated the field of CIE to a significant extent; but it is only a matter of time. With the ease of comparing large amounts of data to provide "comprehensible" conclusions is the erasure of diversity, of plurality, and the contextual knowledge. As multiple scholars have pointed out, the place of origin in Big Data will further the discrimination and the power imbalance that exists in the world (Boyd \& Crawford, 2012; Crawford et al., 2014; Nadege, 2018; Baldo, 2019; Thomas, 2020). Production of data, and the data that is accepted as legitimate, are primarily Western concepts. Thus, certain countries and communities in the Global South would not have what is considered 'legitimate data'. Therefore, it is imperative that the field of CIE takes a revisionist approach to the comparative and the international, to attempt at balancing the scales. Whichever the epistemology that is used to counter the power imbalance, if there is an attempt to approach comparison as a "coconstructing" (Sobe, 2018), progress could be made.

CIE presents itself as one that is inclusive and diverse; it presents as a field of study that is equal. Yet, a critical look at the practice of CIE, specifically in terms of knowledge production, exposes its hegemonic nature. From the textbooks to societies, from theorizing to methodology, elements of hegemonic nature persist. The practitioners in the field are not oblivious to this, though, as elaborated by several CIES presidential addresses spanning decades tackle this problem. This gives hope for a transformation of the field, to one that is not merely inclusive but is pluralistic. In encouraging this transformation, the field would move one step closer to contributing towards "the process of permanent liberation" (Freire, 1972, p. 10) of all people.

\section{Acknowledgements}

The author wishes to acknowledge Chevening Scholarships, the UK government's global scholarship program, funded by the Foreign, Commonwealth and Development Office (FCDO) and partner organizations which funded the author's studies at the University of Oxford, during which this essay was produced.

Minoli Wijetunga is a Sri Lankan scholar completing her MSc Education (Comparative and International Education) at the University of Oxford. She is also a researcher affiliated to the Digital Humanities Laboratory, University of Colombo, Sri Lanka. Her research interests focus on a Global South approaches to education theorizing and practice. 


\section{References}

Arnove, R., Torres, C., \& Franz, S. (2013). Comparative education: The dialectic of the global and the local (Fourth ed.). Lanham, Maryland.

Baldo, B. (2019). Visibility and secrecy: Data protection, privacy and gender in Pakistan. genderit.org. https:/ / www.genderit.org/articles/visibility-and-secrecy-dataprotection-privacy-and-gender-pakistan

Bereday, G. (1964). Sir Michael Sadler's Study of Foreign Systems of Education. Comparative Education Review, 7(3), 307-314.

Bickmore, K., Hayhoe, R., Manion, C., Mundy, K., \& Read, R. (2017). Comparative and international education: Issues for teachers (Second ed.). Toronto.

Boyd, D., \& Crawford, K. (2012). Critical questions for big data: Provocations for a cultural, technological, and scholarly phenomenon. Information, communication $\mathcal{E}$ society, 15(5), 662-679.

Crawford, K., Gray, M. L., \& Miltner, K. (2014). Big data, critiquing big data: Politics, ethics, epistemology, special section introduction. International Journal of Communication, $8,10$.

Freire, P. (1972). Pedagogy of the oppressed. Herder and Herder.

Hickling-Hudson, A. (2007). Improving transnational networking for social justice: 20012004. In Massmann, V, Bray, M, \& Manzon, M. (Eds.), Common interests, uncommon goals: Histories of the World Council of Comparative Education Societies and its members. (pp. 69-82) Springer.

Klerides, E. (2015). (De)constructing modalities of thinking about comparative education through video-use. Research in Comparative and International Education, 10(3), 337-353.

Kubow, P., \& Fossum, P. (2007). Comparative education: Exploring issues in international context (Second ed.). Upper Saddle River, NJ.

Nadege. (2018). Keywords of the internet: The fraying edges of algorithmic production. genderit.org. https: / www.genderit.org/feminist-talk/keywords-internetfraying-edges-algorithmic-production

Phillips, D., \& Schweisfurth, M. (2014). Comparative and international education: An introduction to theory, method, and practice (Second ed.). London; New York.

Ross, H. (2002). The Space between Us: The Relevance of Relational Theories to Comparative and International Education. Comparative Education Review, 46(4), 407432. 
Smith, L. T. (2012). Decolonizing methodologies: Research and indigenous peoples (2nd ed.). London.

Sobe, N. W. (2018). Problematizing comparison in a post-exploration age: Big data, educational knowledge, and the art of criss-crossing. Comparative Education Review, 62(3), 325-343.

Spivak, G. (2003). Can the Subaltern Speak? Die Philosophin, 14(27), 42-58.

Takayama, K., Sriprakash, A., \& Connell, R. (2017). Toward a Postcolonial Comparative and International Education. Comparative Education Review, 61(S1), S1-S24.

Thomas, R. (2020). Citizen data and freedom: The fears of people living with HIV in India. genderit.org. https:/ / www.genderit.org/articles/citizen-data-and-freedom-fearspeople-living-hiv-india

Wittgenstein, L. (1922). Tractus logico-philosophicus. (C. K. Ogden, Trans.) Routledge \& Kegan Paul Ltd.

World Council of Comparative Education Societies. (n.d.) Current Members. Online. https:/ / wcces-online.org/current-members.php 